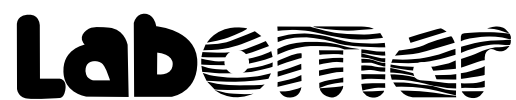

Arquivos de Ciências do Mar

\section{FIRST EVALUATION OF GENOTOXICITY OF MAGAÉ (RJ) ESTUARINE WATERS}

\author{
Primeira avaliação da genotoxicidade das águas \\ do estuário de Macaé (RJ)
}

\author{
Moisés Basilio da Conceição ${ }^{1,2}$, Vitor Oliveira da Costa ${ }^{1}$ \\ Maurício Mussi Molisani ${ }^{3,}$, Laura Isabel Weber ${ }^{1 *}$ \\ ${ }^{1}$ Laboratório de Biologia Molecular - Setor Genotoxicidade, NUPEM, UFRJ, Macaé, RJ, Brazil. \\ ${ }^{2}$ Faculdade Salesiana Maria Auxiliadora, Macaé, RJ. E-Mail: moisesbas@gmail.com \\ ${ }^{3}$ Laboratório de Química, NUPEM, UFRJ. \\ *Author for correspondence: laura.weber.ufrj.macae@gmail.com
}

\begin{abstract}
Low levels of contamination were detected recently on Macaé estuarine waters showing effects in aquatic organisms at different levels. Nonetheless, genotoxicity was not yet evaluated for these waters. A preliminary study was performed using zebrafish Danio rerio by exposing this species to Macaé River estuarine waters. DNA and chromosome damage was evaluated by the comet assay, after 24h and 48h of exposure; and by the micronucleus test, after $72 \mathrm{~h}$ and seven days of exposure. The results showed DNA damage (\% Tail DNA) 5.1-fold higher in fish exposed to estuarine waters than in controls after 48 h of exposure; and significantly higher number of micronuclei/thousand (10-12) in fish exposed to estuarine waters than in controls after three and seven days of exposure. The results of the present study, although preliminary, evidenced genotoxicity of the estuarine waters from the Macaé River, indicating that genotoxicity was at levels to induce DNA and chromosome damage in adult fish.
\end{abstract}

Key words: Macaé River, Danio rerio, Comet Assay, Micronuclei Test, Brazil.

\section{RESUMO}

Níveis baixos de contaminação foram detectados recentemente nas águas estuarinas de Macaé, cujos efeitos crônicos foram descritos em alguns organismos aquáticos em níveis diferentes. No entanto, genotoxicidade ainda não foi avaliada para estas águas. Um estudo

Recebido em: 6/4/2017

Aprovado em: 19/7/2017

Publicado online em: 20/1/2018 
preliminar foi realizado utilizando o peixe-zebra Danio rerio e expondo o peixe às águas estuarinas do Rio Macaé. O dano no DNA e nos cromossomos foi avaliado pelo ensaio do cometa após $24 \mathrm{~h}$ e $48 \mathrm{~h}$ de exposição e pelo teste do micronúcleo após $72 \mathrm{~h}$ e sete dias de exposição. Os resultados mostraram dano no DNA (\% DNA na cauda) 5,1 vezes maior em peixes expostos à água do estuário que nos indivíduos controles após 48 h de exposição; e significativamente maior número de micronúcleos (10-12/1000) nos peixes expostos à água do estuário que nos controles após três e sete dias de exposição. Os resultados do presente estudo, ainda que preliminares, evidenciam genotoxicidade das águas estuarinas do Rio Macaé, indicando que a genotoxicidade está em níveis capazes de induzir dano no DNA e chromossomos de peixes adultos.

Palavras-chaves: Rio Macaé, Danio rerio, Ensaio do cometa, Teste do micronúcleo, Brasil.

\section{INTRODUCTION}

Estuaries usually receivea widerange of materials produced by natural and anthropogenic sources. At the Macaé River basin and estuary (State of Rio de Janeiro), urbanization has increased during the last decade due to petroleum exploration activities at Campos Basin. Nowadays, the Macaé River estuary receives untreated domestic sewage mainly from almost 200,000 inhabitants of the Macaé municipality. Other pollution activities such as the urban runoff, solid waste disposal, agriculture and animal husbandry were potential sources of contaminants to the estuary. Molisani et al., (2013a) estimated that anthropogenic sources were responsible for $62 \%$ of the total emission of $\mathrm{Zn}(29 \mathrm{t} /$ year), $73 \%$ of $\mathrm{Cu}(7.0 \mathrm{t} /$ year), $53 \%$ of $\mathrm{Pb}$ (7.9t/year) and $57 \%$ of Cd (3.7t/year) to the Macaé River basin and estuary; and thus, exceeding the loads from natural sources such as soil runoff and atmospheric deposition. In addition, other activities such as navigation and urbanization have increased the presence of oil derivatives and compounds such as polycyclic aromatic hydrocarbons (PAHs) in the estuary. As a consequence, high PAH levels on mussel from the estuary were found, ranging from 2,876-6,101 $\mu \mathrm{g} / \mathrm{kg}$, which were typical of polluted areas (Santiago et al., 2016). Furthermore, many other biological effects have been found in the estuary, such as the catfish protective enzymatic responses to PAHs from the estuarine waters and sediments (Berenger, 2013); high concentrations of $\mathrm{Cr}$ in mussels (Santiago et al., 2016); fish abnormalities during embryonic development and juvenile growth (Nascimento, 2015); and mortality of amphipods exposed to estuarine sediments (Molisani et al., 2013a). Some metals and PAHs may be genotoxic at certain levels (Jha, 2004), therefore, our aim was to evaluate the levels of genotoxicity that these waters may cause in the known animal model. Genotoxicity tests are very sensitive end-points that affect genetic material at very low levels of contaminants, and allow to find effects in low sensitive species or at higher ontogenetic levels such as adults, which may not be detected with less sensible markers. Therefore, the evaluation of genotoxicity is important to predict the extend of the effects in the local aquatic community.

\section{MATERIAL AND METHODS}

Water samples were taken from one point at the Macaé River in May 2014 during low tide from surface waters near the mouth of the estuary $\left(22^{\circ} 22^{\prime} 11.8^{\prime \prime} \mathrm{S} ; 41^{\circ} 46^{\prime} 33.9^{\prime \prime} \mathrm{W}\right)$ (Figure 1) 


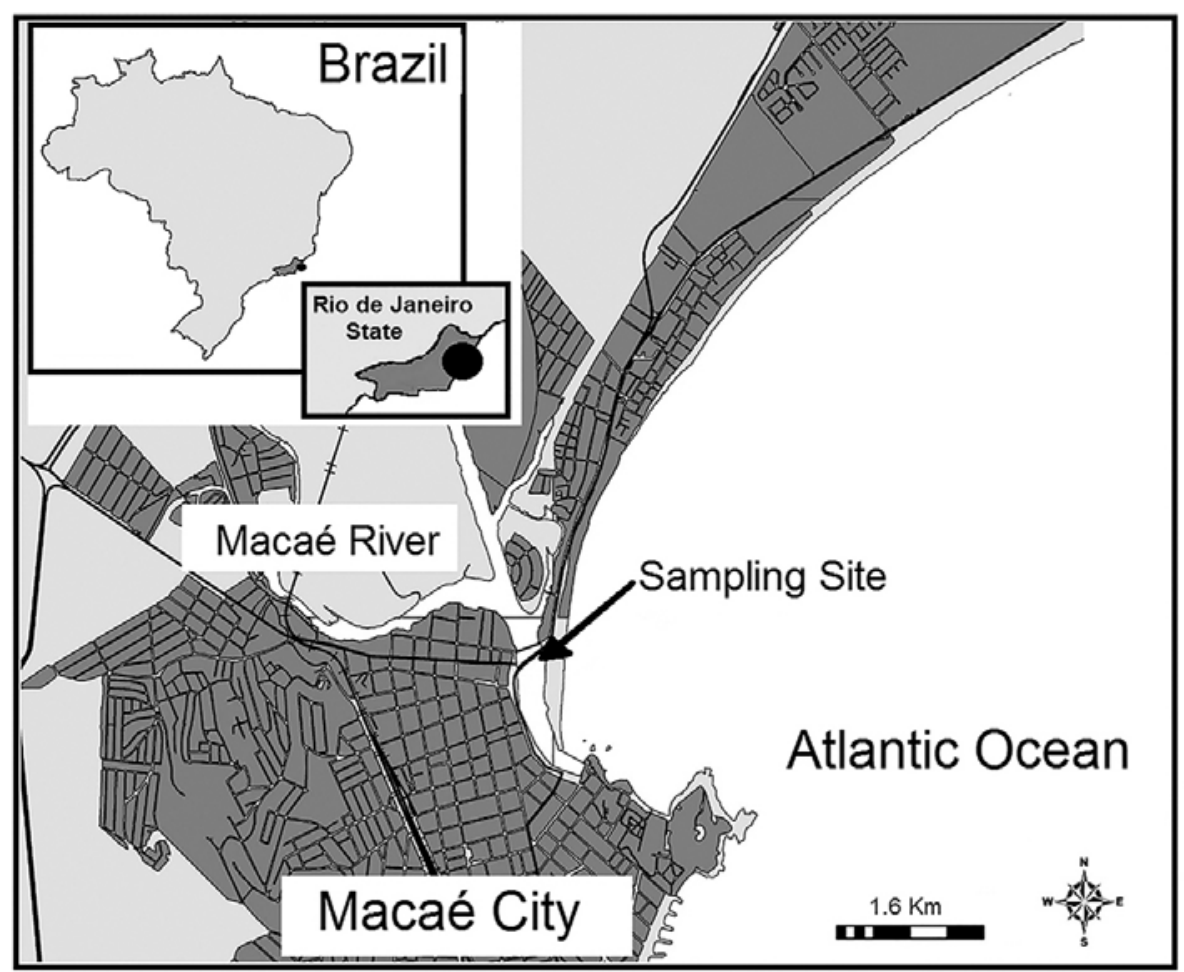

Figure 1 - Sampling site (arrow) at the estuarine region of the Macaé River, Rio de Janeiro state.

and used immediately for the experiment. The salinity was 0.6 at the time of collection and was maintained at $26 \pm 1^{\circ} \mathrm{C}$ during the assays. A total of forty-eight individuals of Danio rerio (Hamilton, 1822), purchased from an aquarium store, were accommodated in $10 \mathrm{~L}$ aquaria and maintained for seven days on filtered and sterilized tap water with constant aeration and fed daily with commercial food (Alcon, MEP 200 complex). Twenty-four animals were transferred to a new aquarium with fresh filtered and sterilized tap water (control unit) and the other 24 were submitted to the freshly collected estuarine water (treated unit). Temperature and aeration were maintained, but feeding was suspended during all the experiment. Six individuals were collected from the experimental units exposed to estuarine waters at each time ( $24 \mathrm{~h}, 48 \mathrm{~h}, 72 \mathrm{~h}$ and $168 \mathrm{~h})$, and an other six per time were simultaneously collected from the control unit. Those collected at $24 \mathrm{~h}$ and $48 \mathrm{~h}$ were used for the Comet assay and those collected at $72 \mathrm{~h}$ and $168 \mathrm{~h}$ were used for the micronuclei test. Animals were sedated in a $0.3 \mathrm{~g} / \mathrm{L}$ benzocaine bath before blood sampling. The comet assay followed the standard protocol with modifications described by Bücker \& Conceição (2012). The comets (nucleoids) of erythrocytes were visualized under epifluorescent Olympus microscope using the DNA-specific stain DAPI (4',6'-diamino-2phenylindole hydrocloride). Approximately one hundred comets per individual have their percentage of DNA in the tail (\% tail DNA) measured by the Comet Score ${ }^{\mathrm{TM}}$ Software, v.1.5 (TriTek Corporation), and it was obtained a mean value per individual. Then, the mean and standard error from individual means were obtained for each treatment and time. The induction factor (IF) was also calculated in accordance to Štrut et al. (2011). Micronuclei $(\mathrm{MN})$ test followed the standard procedure with modifications described by Bücker \& Conceição (2012). For counting MN, the smear was stained with $0.007 \%$ acridine orange and visualized under epifluorescent microscope. The mean number of $\mathrm{MN} /$ thousand was obtained for each treatment and time. Micronucleus were recognized by their characteristic 
structure, which are rounded, have color and texture similar to the nucleus, with a diameter ranging from $1 / 16$ to $1 / 3$ of the diameter of the erythrocyte nucleus. Damage obtained at different units and time were compared using the non-parametric KruskalWallis test $(a=0.05)$ performed by the statistical package STATISTICA, V. 7 (Statsoft Inc.).

\section{RESULTS}

DNA damage as the $\%$ tail DNA after the first $24 \mathrm{~h}$ of exposure was not significantly different from the control. Only after $48 \mathrm{~h}$ of exposure, it was possible to detect significantly higher levels of DNA damage in individuals exposed to the estuarine water of the Macae River compared to the controls $(\mathrm{KW}-\mathrm{H}(1,12)=8.3, p=0.0039)$ (Figure 2a). The number of $\mathrm{MN} /$ thousand was significantly higher in fish exposed to the estuarine waters than the controls, which was evident after the $72 \mathrm{~h}$ of exposition $(\mathrm{KW}-\mathrm{H}(1,12)=8.45, p=0.0036)$ and after the seven days of exposition $(\mathrm{KW}-\mathrm{H}(1,12)=8.67, p=0.0032)$ (Figure $2 \mathrm{~b})$. The induction factors showed increased values with time (Figure 3), obtained from \% tail DNA for $24 \mathrm{~h}$ and $48 \mathrm{~h}$ and from micronuclei/1,000 for 3 and 7 days of exposition.

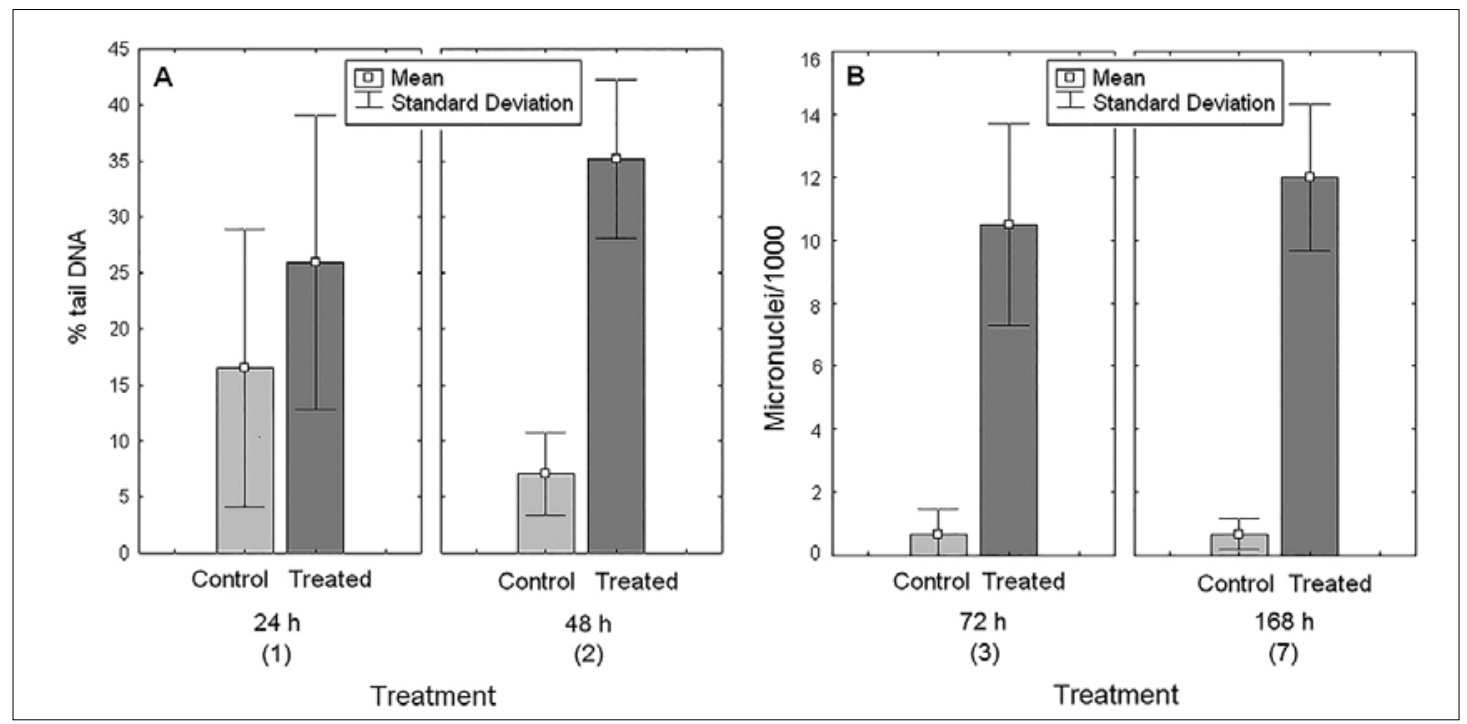

Figure 2 - DNA and chromosome damage observed in the zebrafish Danio rerio after exposed to control and estuarine waters. A) \% comet tail DNA; B) Micronuclei/1000 cels per fish.

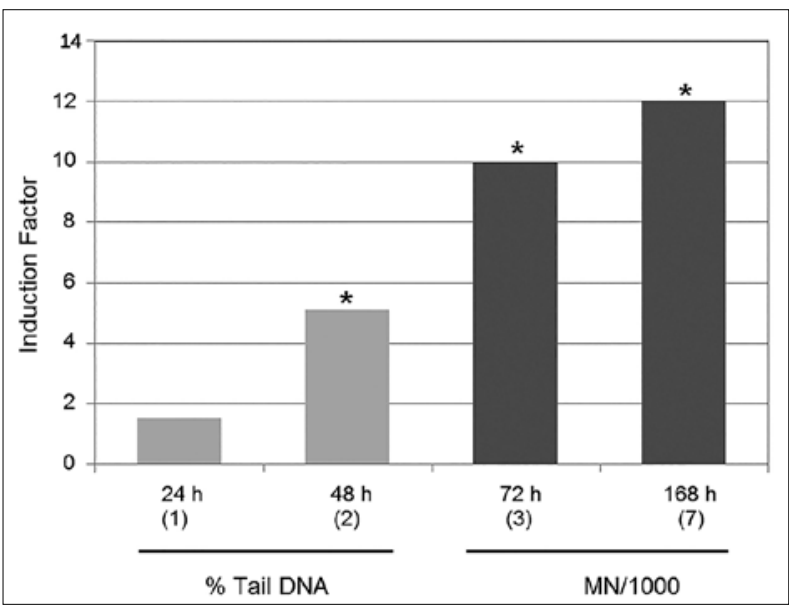

Figure 3 - Induction factor (how many times higher was the damage in the treated units in relation to the controls) for different period of times as evaluated by the comet assay ( $24 \mathrm{~h}$ and $48 \mathrm{~h}$ ) and by the micronuclei test ( 3 and 7 days). 


\section{DISCUSSION}

Genotoxicity tests have proven to be sensitive enough for detecting the effects of xenobiotic on aquatic organisms (Jha, 2004; Ohe et al., 2004; Smit et al., 2009). Aquatic organisms such as fish have been used as sentinels to monitor contamination with genotoxic chemicals (Lemos et al., 2007; Domingos et al., 2009) and Zebrafish used in the present study has been recently evaluated as potential in vivo model for genotoxicity (Chakravarthy et al., 2014).

Low values of DNA damage may be observed as a response of fish acclimatization period. DNA damage observed in this study in the control at the first $24 \mathrm{~h}$ may be explained by this situation, considering that the damage was reduced to $6.0 \%$ after 48 hour. Longer acclimatization periods will always contribute to a more homogeneous response (Obernier \& Baldwin, 2006).

DNA damage observed in the zebrafish exposed to the estuarine waters of the Macaé River, which was 5.1 fold higher than the control after $48 \mathrm{~h}$ of exposure (comet assay), suggests the presence of genotoxic substances. The number of micronuclei found in this study (> $10 \mathrm{MN} /$ thousand) is higher than the values observed for clams at the Guaíba hydrographic basin, which showed values between 4.5 to $6.9 \mathrm{MN} /$ thousand at sites contaminated by urban effluents, metals and agriculture activities (Villela et al., 2007) and similar to values found in fish species (9.0 to $11 \mathrm{MN} /$ thousand) located close to sources of contamination by industrial and urban discharges at Paranaguá estuary (Paraná state) (Domingos et al., 2009).

Among possible genotoxic compounds, we can expect the influence of individual chemicals such as metals, PAHs and other contaminants as well as their possible synergic effects. As demonstrated, Pb enrichment in estuarine sediments $(28-52 \mu \mathrm{g} / \mathrm{g})$ compared to the natural levels, represented by the rock $\mathrm{Pb}$ content (range of $13-23 \mu \mathrm{g} / \mathrm{g}$ ) was attributed to anthropogenic sources such as phosphate fertilizers and agricultural lime correctors, cattle feed supplement, pesticides, atmospheric fallout, solid waste disposal, burning and banned persistent sources such as paintings and gasoline (Molisani et al., 2015). Lead has been considered carcinogen and responsible for disturbing DNA repair process at low and non-cytotoxic concentrations (Bal et al., 2011; Hartwig, 1995).

Polycyclic aromatic hydrocarbons (PAHs) were also observed in the estuary, presenting dual conditions with concentrations typical of pristine areas or polluted coastal environment (Berenger, 2013). This condition is illustrated by the total PAHs in waters which ranged from no detectable concentrations to $120 \mathrm{ng} / \mathrm{g}$, being this maximum value also measured at Guanabara Bay (Rio de Janeiro state), an area which is considered chronically contaminated by oil derivatives (Berenger, 2013; Wagener et al., 2012). In addition, bottom sediments of the estuary also displayed low total PAH concentrations (maximum of $70 \mathrm{ng} / \mathrm{g}$ ), but with the presence of PAH compounds such as pyrene, chrysene, benzo(b)fluoranthene, benzo(a)pyrene (Molisani et al., 2013b) that are described as carcinogenic PAHs and proven to be genotoxic (Hamoutene et al., 2002; Jha, 2004; Lemos et al., 2007; Weber et al., 2013). As a consequence of oil derivative presence in the estuary, high levels of such compounds in mussel from the estuary were found $(2,876-6,101 \mu \mathrm{g} / \mathrm{kg})$ (Santiago et al., 2016), values close to those reported in 2007 for mussel tissue from Guanabara Bay $(4,000-6,000 \mu \mathrm{g} / \mathrm{kg})$ by Francioni et al. (2007). Along the Macaé coast, PAH concentrations in mussel from Santana Island have increased in the last 10 years from $75 \mu \mathrm{g} / \mathrm{kg}$ to $120 \mu \mathrm{g} / \mathrm{kg}$, exemplifying the temporal increasing concentration of such compounds in the coast. 
The presence of PAHs was also confirmed by the higher induction of ethoxyresorufinO-deethylase (EROD) activities in cathfish Genidens genidens following higher PAH concentrations in the estuarine waters, suggested fish responsiveness to oil presence, mainly due to the fact that such EROD values were similar to the magnitude measured in fish during a 24-hr exposure to diesel oil in the laboratory (Berenger, 2013). Finally, the chemical composition of estuarine sediments was assessed and compared to sediment quality guidelines from international (TEL and PEL) and Brazilian coastal areas (Molisani et al., 2013b). From comparison to the threshold effect level (TEL) and probable effect level (PEL) proposed by MacDonald et al. (1996), metals and PAHs in sediments from the Macaé river estuary were below of such levels and should not be associated to adverse biological effects. However, when compared to the Brazilian sediment quality guidelines proposed by Choueri et al. (2009), the results indicated moderate toxicity of these estuarine sediments based on exceeded of maximum $\mathrm{Zn}, \mathrm{Cr}, \mathrm{Cu}, \mathrm{Ni}, \mathrm{Pb}, \mathrm{V}$ and $\mathrm{PAH}$ concentrations for some sites and sampling periods (Molisani et al., 2013b).

The results of the present study, although preliminary, evidenced genotoxicity of the estuarine waters from the Macaé River, indicating that genotoxicity was at levels to induce DNA and chromosome damage in adult fish.

Since the comet assay has been found to be one of the most sensitive end-point for oil contamination in aquatic organisms (Smit et al., 2009) and probably for other source of pollution (Vincent-Huber et al., 2012; Osman, 2014), genotoxicity is gaining popularity as an additional tool for assessing environmental pollution at a multi-biomarker approach (Domingues et al., 2009; Goswami et al., 2014; Costa et al., 2014; Osman, 2014).

Acknowledgements-Wethankthefinancialsupport ofFAPERJ/DCTRE-26/112.569/2012. This study was approved by the Ethical Comitee of UFRJ/Macaé by the Authorization $\mathrm{N}^{\circ}$. MAC004.

\section{LITERATURE CITED}

Bal, W.; Protas, A.M. \& Kasprzak, K.S. Genotoxicity of metal ions: chemical insights. Metal Ions Life Sci., v. 8, p. 319-373, 2011.

Berenger, J. Utilização de marcadores bioquímicos e moleculares em peixes para avaliação do grau de contaminação por hidrocarbonetos policíclicos aromáticos do estuário do rio Macaé. 2013. Master's Thesis, Environmental Sciences and Conservation, Universidade Federal do Rio de Janeiro, Macaé, 2013.

Bücker, A. \& Conceição, M.B. Genotoxicity evaluation of tilapia (Oreochromis niloticus) exposed to waters from two sites of Itajaí-Açu River (SC, Brazil). J. Braz. Soc. Ecotoxicol., v. 7, n. 2, p. 63-68, 2012.

Chakravarthy, S.; Sadagopan, S.; Nair, A. \& Sukumaran, S.K. Zebrafish as an in vivo highthroughput model for genotoxicity. Zebrafish, v. 11, n. 2, p. 154-166, 2014.

Choueri, R.B.; César, A.; Abessa, D.M.S.; Torres, R.J.; Morais, R.D.; Riba, I.; Pereira, C.D.S.; Nascimento, M.R.L.; Mozeto, A.A. \& DelValls, T.A. Development of site-specific sedimet quality guidelines for Norht and South Atlantic littoral zones: comparison against national and international sediment quality benchmarks. J. Hazard. Mater. v. 170, p.320-331, 2009. 
Costa, P.M.; Pinto, M.; Vicente, A.M.; GonCalves, C.; Rodrigo, A.P.; Louro, H.; Costa, M.H.; Caeiro, S. \& Silva, M.J. An integrative assessment to determine the genotoxic hazard of estuarine sediments: combining cell and whole-organism responses. Frontiers Gen., v.5, p. 1-12, 2014.

Domingos, F.X.V.; Assis, H.C.S.; Silva, M.D.; Damian, R.C.; Almeida, A.I.M.; Cestari, M.M.; Randi, M.A.F. \& Ribeiro, C.A.O. Anthropic impact evaluation of two Brazilian estuaries through biomarkers in Fish. J. Braz. Soc. Ecotoxicol., v.4, n. 1-3, p. 21-30, 2009.

Francioni, E.L.; Wagener, A. de L.R.; Scofiel, A.L.; Depledge, M. \& Cavalier, B. Evaluation of the mussel Perna perna as a biomarker of polycyclic aromatic hydrocarbon (PAH) exposure and effects. Mar. Pollut. Bull., v. 54, p. 329-338, 2007.

Goswami, P.; Thirunavukkarasu, S.; Godhantaraman, N. \& Munuswamy, N. Monitoring of genotoxicity in marine zooplancton induced by toxic metals in Ennore estuary, Southeast coast of India. Mar. Poll. Bull., v. 88, p. 70-80, 2014.

Hamoutene, D.; Payne, J.F.; Rahimtula, A. \& Lee, K. Use of the comet assay to assess DNA damage in hemocytes and digestive gland cells of mussels and clams exposed to water contaminated with petroleum hydrocarbons. Mar. Environm. Res., v. 54, p. 471-474, 2002.

Hartwig, A. Current aspects in metal genotoxicity. Biometals, v. 8, n. 1, p. 3-11, 1995.

Jha, A.N. 2004. Genotoxical studies in aquatic organisms: an overview. Mut. Res., v. 552, p. 1-17.

Lemos, C.T.; Rödel, P.M.; Terra, N.R.; Oliveira, N.C.D. \& Erdtmann, B. River water genotoxicity evaluation using micronucleus assay in fish erythrocytes. Ecotoxicol. Environm. Safety, v. 66, p. 391-401, 2007.

MacDonald, D.D.; Carr, R.S.; Calder, F.D.; Long, E.R. \& Ingersoll, C.G. Development and evaluation of sediment quality guidelines for Florida coastal waters. Ecotoxicology, v. 5, p. 253-278, 1996

Molisani, M.M.; Costa, R.N.; Cunha, P.; Rezende, C.E.; Ferreira, M.I.P. \& Esteves, F.A. Acute toxicity bioassay with the amphipod, Grandidierella bonnieroides S. after exposure to sediments. Bull. Environm. Contamin. Toxicol., v. 90: p. 79-84, 2013 a.

Molisani, M.M.; Esteves, F.A.; Lacerda, L.D. \& Rezende, C.E. Emissões naturais e antrópicas de nitrogênio, fósforo e metais para a bacia do rio Macaé (Macaé, RJ, Brasil) sob influência das atividades de exploração de petróleo e gás na Bacia de Campos. Química Nova, v. 36, n. 1, p. 27-33, 2013b.

Molisani, M.M.; Noronha, F.R.; Schultz, M.S.; Rezende, C.E.; Almeida, M.G. \& Silveira, C.S. Mismatch between sediment metal distribution and pollution source gradient: a case study of a small-size drainage basin (Southeastern Brazil). Bull. Environm. Contamin. and Toxicol., v. 94, p. 770-776, 2015.

Nascimento, R.S. Avaliação da morfologia e expressão gênica de biomarcadores durante o desenvolvimento embrionário de Danio rerio sob efeito de substancias tóxicas ou bioativas de águas poluídas. Master's Thesis, Environmental Sciences and Conservation, Universidade Federal do Rio de Janeiro, Macaé, 2015.

Obernier, J.A. \& Baldwin, R.L. Establishing an appropriate period of acclimatization following transportation of laboratory animals. ILAR Journal, v. 47, n. 4, p. 364-369, 2006. 
Ohe, T.; Watanabe, T. \& Wakabayashi, K. Mutagens in surface waters: a review. Mut. Res., v. 567, p. 109-149, 2004.

Osman, A.G.M. Genotoxicity tests and their contributions in Aquatic Environmental Research. Jour. Environm. Protec., v. 5, p. 1391-1399, 2014.

Santiago, I.U.; Molisani, M.M.; Nudi, A.A.H.; Scofield, A.L.; Wagener, A.L.R. \& Limaverde Filho, A.M. Hydrocarbons and trace metals in mussels in the Macaé coast: Preliminary assessment for a coastal zone under influence of offshore oil field exploration in Southeastern Brazil. Mar. Poll. Bull., v. 103, p. 349-353, 2016.

Smit, M.G.D.; Bechmann, R.K.; Hendriks, A.J. \& Sannt, S. Relating biomarkers to wholeorganism effects using species sensitivity distributions: a pilot study for marine species exposed to oil. Environm. Toxicol. Chem., v. 28, n. 5, p. 1104-1109, 2009.

Štrut, M.; Traven, L.; Štambuk, A.; Kralj, S.; Žaja, M.; Mićović, V. \& Klobučar, G. Genotoxicity of marine sediments in the fish hepatoma cell lines PLHC-1 as assessed by the comet assay. Toxicology In Vitro, v. 25, p. 308-314, 2011.

Villela, I.V.; Oliveira, I.M.; Silveira, J.C.; Dias, J.F.; Henriques, J.A.P. \& Silva, J. 2007. Assessment of environmental stress by the micronucleus and comet assays on Limnoperna fortunei exposed to Guaíba hydrographic regions samples (Brazil) under laboratory conditions. Mut. Res., v. 628: p. 76-86, 2007.

Vincent-Hubert, F.; Heas-Moisan, K.; Munschy, C. \& Tronczynski, J. Mutagenicity and genotoxicity of suspended particulate matter in the Seine river estuary. Mut. Res., v. 741, p. 7-12, 2012.

Wagener, A.L.R.; Meniconi, M.F.G.; Hamacher, C,; Farias, C.O.; da Silva, G.C.; Gabardo, I.T. \& Scofield, A.L. Hydrocarbons in sediments of a chronically contaminated bay: the challenge of source assignment. Mar. Pollut. Bull., V. 64, p. 284-294, 2012.

Weber, L.I.; Carvalho, L.; Sá, N.; Beraldini, N.; Souza, V. \& Conceição, M. Genotoxic effects of the water-soluble fraction of heavy oil in the brackish/freshwater amphipod Quadrivisio aff. lutzi (Gammaridea) as assessed using the comet assay. Ecotoxicology, v. 22, p. 642-655, 2013. 